\title{
PENEGAKAN HUKUM PIDANA BAGI PELAKU PENYEBAR KONTEN PORNOGRAFI DI MEDIA SOSIAL DITINJAU DARI UNDANG-UNDANG INFORMASI DAN TRANSAKSI ELEKTRONIK
}

\author{
Oleh: \\ Gomgom T P Siregar ${ }^{1)}$ \\ Indra Purnanto S. Sihite ${ }^{2)}$ \\ Universitas Darma Agung, Medan ${ }^{1), 2)}$ \\ E-mail: \\ gomgomsiregar@gmail.com \\ sisparno@gmail.com
}

\begin{abstract}
The handling of cases of spreading pornographic photos through the social media Facebook is not subject to temporary detention when conducting an investigation because based on the investigator's belief, the perpetrator will not run away, nor will he remove evidence, but what happens is evidence from the perpetrator. Using normative juridical research, which examines the regulations of Law No. 19/2016 on ITE. Criminal law enforcement for perpetrators of spreading pornographic content on social media in terms of the Law on Information and Electronic Transactions Article 45 paragraph 1 of Law No. 19 of 2016 on ITE, the threat of punishment for the perpetrators of spreading can be sentenced to a maximum imprisonment of 6 years and a maximum fine of Rp. 1,000,000,000 billion.
\end{abstract}

Keywords: Content Spreader, Pornography, Criminal Sanctions.

\begin{abstract}
ABSTRAK
Penanganan kasus penyebaran foto porno melalui media sosial facebook tidak dilakukan penahanan sementara saat melakukan penyidikan karena berdasarkan keyakinan penyidik, pelaku tidak akan melarikan diri, juga tidak menghilangkan alat bukti, namun yang terjadi adalah barang bukti dari pelaku. Menggunakan penelitian yuridis normative, yakni mengkaji peraturan UU No 19 Tahun 2016 tentang ITE. Penegakan Hukum Pidana Bagi Pelaku Penyebar Konten Pornografi Di Media Sosial Ditinjau Dari Undang-Undang Informasi Dan Transaksi Elektronik Pasal 45 ayat 1 UU No 19 Tahun 2016 tentang ITE ancaman hukuman bagi para pelaku penyebaran dapat dipidana dengan penjara paling lama 6 tahun dan maksimal denda Rp. 1.000.000.000 milyar.
\end{abstract}

Kata Kunci :Penyebar Konten, Pornografi, Sanksi Pidana. 


\section{PENDAHULUAN}

\section{A. Latar Belakang}

Penyebar video porno yang diduga mirip artis Syahrini, lantaran ada sakit hati. Akun yang diunggah di akun instrgram milik pribadinya (a) danunyinyir99 dan akun Instagram @ rumpi.manja.official. Syahrini melaporkan perkara itu ke polisi pada 12 Mei 2020 atas dugaan pencemaran nama baik dan pornografi.

Pengakuan pelaku yang bersangkutan (MS), ada suatu kebencian ke korban. Karena dia salah satu fans publik figur lain dan menuduh korban Syahrini ini mengambil orang terdekat fansnya. Pelaku MS dijerat Pasal 27 dan Pasal 45 Undang-Undang Nomor 19 Tahun 2016 tentang Perubahan atas UndangUndang Nomor 11 tahun 2008 tentang Informasi dan Transaksi Elektronik, juga Pasal 4 ayat (1) Undang-Undang Nomor 44 Tahun 2008 tentang Pornografi, dengan ancaman paling lama 12 tahun dan denda Rp 250.000.0000 juta hingga Rp 6.000.000.0000 miliar rupiah. Penyidik juga menemukan akun lain yang diduga turut menyebarkan video tersebut.

Manipulasi digital membutuhkan foto-foto sumber, tetapi sejumlah pornografi dihasilkan tanpa aktor manusia sama sekali. Gagasan tentang pornografi yang sepenuhnya dihasilkan oleh komputer sudah dipikirkan sejak dini sebagai salah satu daerah aplikasi yang paling jelas untuk grafik komputer dan pembuatan gambar tiga dimensi. Pembuatan gambar-gambar lewat komputer yang sangat realistic menciptakan dilemma-dilema etika baru.

Ketika gambar-gambar khayal tentang penyiksaan atau pemerkosaan disebarkan secara luas, para penegak hukum menghadapi kesulitankesulitan tambahan untuk menuntut gambar-gambar otentik yang menampilkan perbuatan kriminal, karena kemungkinan gambar-gambar itu hanyalah gambar sintetik. Keberadaan foto-foto porno palsu dari para selebriti memperlihatkan kemungkinan untuk menggunakan gambar-gambar palsu untuk melakukan pemerasan atau mempermalukan siapapun yang difoto atau difilmkan, meskipun ketika kasus-kasus itu menjadi semakin lazim, pengaruhnya kemungkinan akan berkurang. Akhirnya, generasi gambar-gambar yang sama sekali bersifat sintetik, yang tidak merekam peristiwa yang sesungguhnya menantang kritik kritik konvensional terhadap pornografi dan pornoaksi.

Mengenal pornografi terlalu dini jg dapat membuat seseorang melakukan kejahatan seksual seperti pelecehan seksual. $77 \%$ pelaku pelecehan terhadap anak laki-laki, dan $87 \%$ pelaku pelecehan terhadap anak perempuan mengaku kebiasaan melihat pornografi lah yg mendorong tindakan kriminal mereka.

Ada beberapa ancaman dalam UU ITE, antara lain:

1. Larangan mendownload Pasal 5 dan Pasal 31

2. Larangan memiliki, meyimpan, dan mempertontonkan pasal 6 dan 32

3. Larangan Memproduksi, dan memperjualbelikan Pasal 4 ayat 1 dan 29

4. Larangan meyediakan jasa pornografi Pasal 4 ayat 2 dan 30 . 


\section{B. Rumusan Masalah}

1. Bagaimanakah Pengaturan Hukum Yang Berkaitan Dengan Pornografi Menurut Peraturan Perundang-undangan?

2. Bagaimana Batasan-Batasan Kriteria Atas Konten Yang Dikecualikan Dalam Tindak Pidana Kesusilaan ?

3. Bagaimana Penegakan Hukum Pidana Bagi Pelaku Penyebar Konten Pornografi Di Media Sosial Ditinjau Dari Undang-Undang Informasi Dan Transaksi Elektronik?

\section{Tujuan Penelitian}

1. Untuk mengetahui Pengaturan Hukum Yang Berkaitan Dengan Pornografi Menurut Peraturan Perundang-undangan.

2. Untuk Mengetahui BatasanBatasan Kriteria Atas Konten Yang Dikecualikan Dalam Tindak Pidana Kesusilaan.

3. Untuk Mengetahui Penegakan Hukum Pidana Bagi Pelaku Penyebar Konten Pornografi Di Media Sosial Ditinjau Dari Undang-Undang Informasi Dan Transaksi Elektronik.

\section{METODE PENELITIAN}

Penelitian dalam penulisan ini yuridis normatif yaitu penelitian hukum yang dilakukan dengan cara meneliti ke perpustakaan atau melalui peraturan perundang-undangan yang terkait dengan penelitian yakni UU ITE Nomor 11 Tahun 2008 sebagaimana dirubah menjadi UU Nomor 19 Tahun 2016.

\section{Sumber Data}

Dilihat dari penelitian

kepustakaan (library reach), dapat dibagi atas 3 (tiga) kelompok, yaitu:

a. Bahan Hukum Primer, yaitu Kitab Undang-Undang Hukum Pidana, UndangUndang Nomor 44 Tahun 2008 tentang Tentang Pornografi, Undang-undang Nomor 4 Tahun 1979 tentang Kesejahteraan Anak. Kitab Undang-undang Hukum Pidana

b. Bahan Hukum Sekunder, seperti Jurnal Hukum, Skripsi dan penelitian yang berkenaan dengan pembahasan konten pornografi dalam media sosial.

c. Bahan Hukum Tersier, yaitu bahan yang dapat mendukung bahan-bahan hukum premier dan sekunder, antara lain kamus hukum, kamus bahasa Indonesia, majalah, jurnal ilmiah dan sebagainya.

III. HASIL

DAN

\section{PEMBAHASAN}

A. Pengaturan Hukum Yang

Berkaitan Dengan Pornografi

Menurut Peraturan

Perundang-Undangan

Pengaturan tentang hukuman bagi para pelaku penyebar konten pornografi ini juga diatur di dalam Pasal 27 ayat (1) UU Nomor 11 tahun 2008 Tentang Informasi dan Transaksi Elektronik (UU ITE) mengatur:

"Setiap Orang dengan sengaja dan tanpa hak mendistribusikan dan/atau mentransmisikan dan/atau membuat dapat diaksesnya Informasi Elektronik dan/atau Dokumen Elektronik yang 
memiliki muatan yang melanggar kesusilaan."

Konten yang dilarang untuk didistribusikan/disebarkan atau ditransmisikan adalah konten yang di dalamnya terdapat muatan:

1. Kesusilaan/pornografi (Pasal 27 ayat (1) UU ITE jo. Pasal 45 ayat (1) UU 19/2016)

2. Perjudian (Pasal 27 ayat (2) UU ITE jo. Pasal 45 ayat (2) UU 19/2016)

3. Penghinaan dan/atau pencemaran nama baik (Pasal 27 ayat (3) UU ITE jo. Pasal 45 ayat (3) UU 19/2016)

4. Pemerasan

dan/atau pengancaman (Pasal 27 ayat (4) UU ITE jo. Pasal 45 ayat (4) UU 19/2016)

5. Berita bohong dan menyesatkan (Pasal 28 ayat (1) UU ITE jo. Pasal 45A ayat (1) UU 19/2016)

Kebencian atau permusuhan individu dan/atau kelompok masyarakat tertentu berdasarkan atas suku, agama, ras, dan antargolongan (SARA). (Pasal 28 ayat (2) UU ITE jo. Pasal 45A ayat (2) UU 19/2016)

Ancaman pidana terhadap pelanggar diatur dalam Pasal 45 ayat (1) UU ITE, yaitu ancaman pidana penjara paling lama 6 (enam) tahun dan/atau denda paling banyak 1 (satu) milliar rupiah.

\section{Pasal 4}

1. Setiap orang dilarang memproduksi, membuat, memperbanyak, menggandakan, menyebarluaskan, menyiarkan, mengimpor, mengekspor, menawarkan, memperjualbelikan, menyewakan, atau menyediakan pornografi yang secara eksplisit memuat: alat kelamin
Pasal 29 UU Pornografi yang berbunyi:

Setiap orang yang memproduksi, membuat, memperbanyak, menggandakan, menyebarluaskan, menyiarkan, mengimpor, mengekspor, menawarkan, memperjualbelikan, menyewakan, atau menyediakan pornografi sebagaimana dimaksud dalam Pasal 4 ayat (1) dipidana dengan pidana penjara paling singkat 6 (enam) bulan dan paling lama 12 (dua belas) tahun dan/atau pidana denda paling sedikit Rp 250.000.000,00 (dua ratus lima puluh juta rupiah) dan paling banyak Rp 6.000.000.000,00 (enam miliar rupiah).

Ada beberapa kumpulan alamat situs download dan streaming video lewat handphone android terbaru yaitu:

1. www.vuclip.com

2. http://tubidy.mobi/

3. www.tubezen.com

4. http://mobtube.info/

5. http://waptrick.com/

6. www.zedge.net

7. http://freemobilvideos.com/

8. http://www.mv3gp.com/

9. http://mywibes.me/

10. http://3gpfind.com/

11. http://duoberry.com/

12. http://youtubemyway.com/

13. http://videos.yaaya.mobi/

14. www.wapdam.com

15. http://3gpsearch.com

16. http://keepvid.com

17. http://vkwap.com/ytube/

18. www.gratisindo.com

19. www.gamawap.com

20. www.ganool.com

Bahwa akses pornografi di masa pandemi ini terutama naik drastis pada pukul 03.00 dan 07.00 
pagi serta pukul 13.00 siang. Meski di masa pandemic covid seperti yang terjadi saat ini banyak remaja sekolah dari rumah karena tidak diberikan kesempatan untuk sekolah.jadi waktu mereka diluar pantauan orangtua sering membuka situs-situs porn ini. Perlunya diadakan penyuluhan Bahaya Pornografi dan Penyuluhan Diet serta Detoks Gadget kepada masyarakat.

Konten negatif tidak terbatas pada konten perjudian dan pornografi saja, melainkan bisa berupa konten pencemaran nama baik, pemerasan atau pengancaman, atau konten yang berisikan muatan suku, agama, ras, dan antargolongan (SARA) serta konten lainnya yang dilarang oleh peraturan perundang-undangan (seperti penipuan, pelanggaran hak cipta, pemalsuan, dan lain lain).

\section{B. Batasan-batasan kriteria atas konten yang dikecualikan dalam tindak pidana kesusilaan}

Pembatasan-perbuatan yang dikategorikan melanggar kesusilaan (aanstotelijk van de eerbaarheid) ini penting, mengingat hukum pidana harus dilaksanakan secara obyektif. Keobyektifan penegakan hukum pidana berarti pasal-pasal yang dicantumkan dalam aturan hukum pidana tidak menimbulkan interpretasi yang bermacam-macam. Sedangkan istilah melanggar kesusilaan (aanstotelijk van de eerbaarheid) yang dipakai KUHP ternyata sangat relatif, tergantung pada ruang dan waktu secara obyektif dapat menimbulkan berbagai macam penafsiran.

Larangan pornografi yang membuat persenggamaan menyimpang seperti: a Aktivitas seksual dengan mayat b Aktivitas seksual dengan binatang

c Oral seks

d Anal seks

e Lesbian atau homoseksual

f Persenggamaaan dengan anak-anak, sodomi (pedofilia)

g Larangan pornografi yang memuat kekerasan seksual

$\mathrm{h}$ Larangan pornografi yang memuat mastubarsi atau onani

i Laragan pornografi memuat ketelanjangan atau tampilan ketelanjangan

j Larangan pronografi yang memuat alat kelamin

$\mathrm{k}$ Larangan pornografi memuat pornografi anak

Batasan-batasan kriteria atas konten yang dikecualikan dalam tindak pidan kesusilaan adalah: Kepentingan pribadi, konten kesusilaan dikecualikan untuk kepentingan pribadi. Perbuatan membuat adalah tidak termasuk untuk dirinya sendiri dan kepentingan sendiri, membuat pornografi menjadikan orang lain sebagai objek atau model maka melanggar Pasal 9 UU Nomor 44 Tahun 2008 dan dijatuhi hukuman penjara paling singkat 1 tahun dan paling lama 12 tahun. Perbuatan membuat pornografi tidak dibatasi hanya si pembuat pornografi itu sendiri, seperti:

a Ketelanjangan atau tampilan yang mengesankan

ketelanjangan;

b Mastubarsi atau onani

c Alat kelamin

d Persenggamaan yang menyimpang, kekerasan seksual atau pornografi anak sebagaimana dimaksud Pasal 4 ayat 1 huruf $a, b$ dan $f$.

Pengaturan konten-konten yang dikecualikan dalam tindak pidana kesusilaan dalam perundang- 
undangan tersebut dilakukan dengan 2 cara yaitu:

1. Membuat peraturan khusus yang mengatur mengenai pengecualian tersebut dalam berbagai tingkat/jenis peraturan perundangundangan;

2. Tanpa mengeluarkan peraturan resmi dalam bentuk apapun tetapi disesuaikan dengan hukum yang hidup dimasyarakat.

Yang dimaksud Informasi elektronik dan/atau dokumen elektronik yang memiliki muatan melanggar kesusilaan adalah pornografi. Jika pornografi itu dibuat untuk tujuan dan kepentingan pendidikan sebagaimana dimaksud Pasal 6 dan penjelasannya Pasal 14 UU No 44 Tahun 2008 adalah dikecualikan tentu penyebarannya pun dikecualikan. Pengecualian tersebut memenuhi syarat-syarat dan perixinan yang ditentukan dalam undang-undang sehingga perpustakaan, laboratorium, atau sarana pendidikan lain menjadi bagian atau hak miliki lembaga pendidikan tersebut.

Batasan-batasan kriteria atas konten yang dikecualikan dalam tindak pidana kesusilaan dikecualikan untuk kepentingan pribadi. Perbuatan membuat adalah tidak termasuk untuk dirinya sendiri dan kepentingan sendiri, membuat pornografi menjadikan orang lain sebagai objek atau model seperti: Ketelanjangan atau tampilan yang mengesankan ketelanjangan;Mastubarsi atau onani, Alat kelamin dan Persenggamaan yang menyimpang, kekerasan seksual atau pornografi anak sebagaimana dimaksud Pasal 4 ayat 1 huruf a, b dan f. 
Upaya Direktorat Kriminal Khusus Subdit Cybercrime dalam menanganai tindak pidana cybercrime yang berkaitan dengan pornogrfi dan pornoaksi di wilayah Sumatera Utara, melalui subdit II sudah berhasil melakukan penyelidikan terhadap kasus-kasus penawaran perempuan yang bisa dipergunakan untuk pekerja seks komersil. Pada tahun 2017, misalnya. Polisi mengamankan Octafira Rahayu Kardianti als Nanda yang merupakan pemilik akun facebook nanda aulia Lubis. Dimana menawrkan wanita tunasusila dengan tariff $\mathrm{Rp}$. 3.000.000/ per malam. Mucikari mendapatkan upah Rp.500.000/orang jika berhasil. Kemudian Polisi melakukan penyelidikan dengan berpura-pura sebagai Pelanggan di salah satu hotel sehingga mengamankan 5 orang perempuan pekerja seks komersial dengan inisial SDT, RS, AA, DA, L

Para pelaku disangkakan melakukan tindak pidana dengan pasal yang dilanggar yaitu Pasal 45 ayat 1 jo Pasal 27 ayat 1 UU NO 19 Tahun 2016 dan Pasal 30 jo Pasal 4 UU No 44 Tahun 2008 tentang Pornografi, dan Pasal 2 ayat 1 UU No 21 Tahun 2007 tentang Trafficking dengan ancaman hukuman penjara 6 tahun penjara.

Kementrian Komunikasi dan Informatika disediakan akun pelaporan adanya konten yang mengandung asusila, yakni dapat diakses dalam link https://www.aduankonten.id ini yakni berisi tentang hal-hal ini:

\section{Lacak Aduan Konten}

Pantau status terakhir aduan Anda dengan memasukkan nomor aduan.

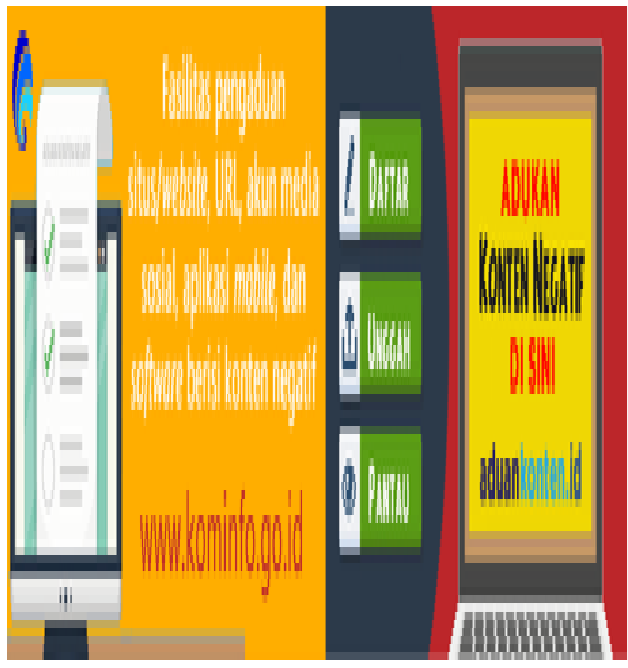

\section{Tentang Aduan Konten}

Situs ini merupakan fasilitas pengaduan konten negatif baik berupa situs/website, URL, akun media sosial, aplikasi mobile, dan software yang memenuhi kriteria sebagai Informasi dan/atau Dokumen Elektronik bermuatan negatif sesuai peraturan perundang-undangan.

Setiap orang berhak untuk menyampaikan pengaduan konten negatif dengan cara mendaftarkan diri, mengunggah tautan (link) serta screenshot situs atau konten yang dilaporkan disertai alasan, dan memantau proses penanganan yang dilakuan oleh Tim Aduan Konten. Mari berpartisipasi aktif dan menjadikan internet lebih aman, nyaman, dan bermanfaat dengan berkurangnya konten-konten negatif.

\section{Pendaftaran Pelapor}

Apakah ada konten yang ingin Anda adukan? silakan daftar dibawah ini. Setelah itu konfirmasi.

Pengaduan dapat dilakukan melalui formulir pengaduan seperti di Kementerian Komunikasi dan 
Informatika dengan link http://trustpositif.kominfo.go.id atau dapat diakses di formulir pengaduan portal polisi online di http://www.polisionline.net/p/formpengaduan.html atau juga dapat kirim e-mail lewat aduan konten dari Kominfo aduankonten@mail.kominfo.go.id

Selain itu, masyarakat juga dapat melihat keaslian gambar atau foto langsung lewat Google. Dapat dilakukan dengan cara membuka ikon Google Image, klik ikon kamera lalu akan muncul dua ikon Tempel URL gambar atau Upload gambar. Klik salah satu pilihan seusai dengan kebutuhan, lalu akan muncul gambar, artikel atau keterangan pada hasil pencarian.

Di platform media sosial seperti Facebook dan Twitter juga menyediakan laporan langsung jika ada konten-konten yang negatif. Seperti di Facebook, dapat di klik pojok kanan atas pada postingan, klik laporan kiriman/laporan foto, setelah itu pilih jenis laporan dan pilih kiriman ke Facebook untuk ditinjau. Untuk pengguna Twitter, klik simbol tiga titik diatas kanan kiriman, setelah itu klik 'report tweet' atau 'laporkan kicauan.

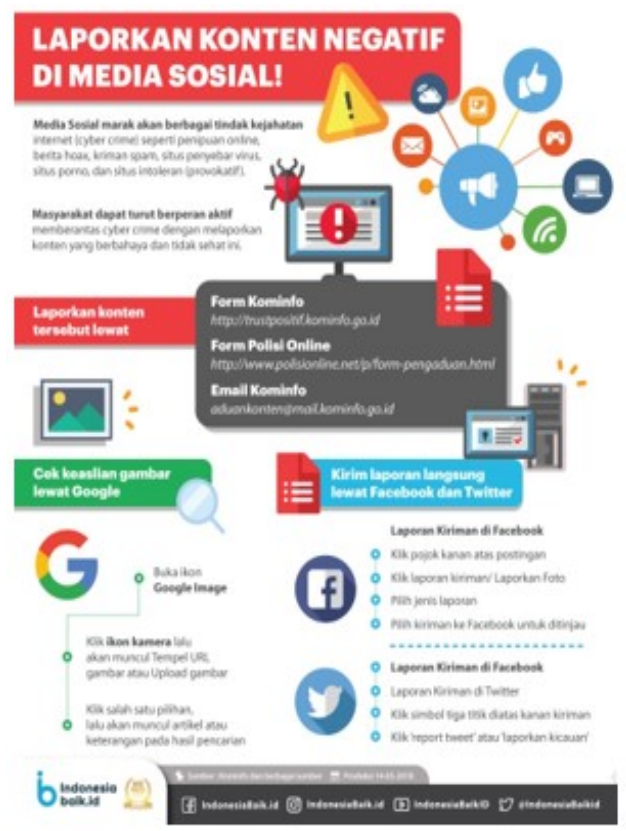

Gambar 1 Cara Melaporkan Konten Negatif di Media Sosial

\section{Sumber :}

http://indonesiabaik.id/public/upload s/post/2104/1405 Laporkan Konten Negatif di Media Sosial GP.jpg

Media sosial saat ini marak akan berbagai tindak kejahatan internet (cyber crime), diantaranya terdiri dari kategori Pornografi/Pornografi Anak, Perjudian, Pemerasan, Penipuan, Kekerasan Anak, Fitnah/Pencemaran Nama Baik, Pelanggaran Kekayaan Intelektual, Produk dengan Aturan Khusus, Provokasi SARA, Berita Bohong, Terorisme/Radikalisme, dan Informasi/Dokumen Elektronik Melanggar UU.

Konten yang paling banyak diadukan ke Kominfo selama 2019 berupa muatan pornografi, jumlahnya mencapai 244.738 aduan. Konten aduan terbanyak kedua adalah fitnah dengan jumlah total sebanyak 57.984. Kominfo juga menerima aduan 
masyarakat yang masuk kategori konten yang meresahkan masyarakat, jumlahnya mencapai 53.455. Konten lainnya yang mendominasi aduan masyarakat sepanjang 2019 adalah konten terkait perjudian 19.970, konten penipuan sebanyak 18.845 , dan konten hoaks 15.361. Aduan lainnya yang diterima Kominfo selama 2019 antara lain berkaitan dengan SARA, kekerasan terhadap anak, terorisme dan penyalahgunaan obat terlarang. ${ }^{1}$

Selain menerima aduan masyarakat mengenai konten negatif, Kominfo secara aktif melakukan penelurusan untuk melakukan verifikasi dan validasi terhadap temuan konten, melalui mesin AIS yang dikelola Subdirektorat Pengendalian Konten Internet, Direktorat Pengendalian Aplikasi Informatika, Direktorat Jenderal Aplikasi Informatika.

Jika termasuk negatif, maka akan mendapatkan rekomendasi penapisan dari verifikator. Apabila konten berkaitan dengan kewenangan instansi lain, konten akan diteruskan ke instasi tersebut untuk mendapatkan rekomendasi penapisan.

\section{KESIMPULAN DAN} SARAN

\section{A Kesimpulan}

1. Pengaturan Hukum Yang Berkaitan Dengan Pornografi Menurut Peraturan PerundangUndangan diatur dalam Pasal 27 ayat 1 ayat 2 ayat 3 Undangundang Inoformasi dan Transaksi Elektronik Nomor 11 Tahun 2008 sebagaimana diperbaharui

${ }^{1}$ https://kominfo.go.id/content/detai 1/23717/ada-431065-a duan-konten-negatif-
UU Nomor 19 Tahun 2016 dan Pasal 45 ayat 1 Undang-undang Nomor 44 Tahun 2008 tentang Pornografi.

2. Batasan-batasan kriteria atas konten yang dikecualikan dalam tindak pidana kesusilaan dikecualikan untuk kepentingan pribadi. Perbuatan membuat adalah tidak termasuk untuk dirinya sendiri dan kepentingan sendiri, membuat pornografi menjadikan orang lain sebagai objek atau model seperti: Ketelanjangan atau tampilan yang mengesankan ketelanjangan;Mastubarsi atau onani, Alat kelamin dan Persenggamaan yang menyimpang, kekerasan seksual atau pornografi anak sebagaimana dimaksud Pasal 4 ayat 1 huruf $a, b$ dan $f$.

3. Penegakan Hukum Pidana Bagi Pelaku Penyebar Konten Pornografi Di Media Sosial Ditinjau Dari Undang-Undang Informasi Dan Transaksi Elektronik Pasal 45 ayat $1 \mathrm{UU}$ No 19 Tahun 2016 tentang ITE ancaman hukuman bagi para pelaku penyebaran dapat dipidana dengan penjara paling lama 6 tahun dan maksimal denda Rp. 1.000.000.000 milyar.

\section{B. Saran}

1. Seharusnya dalam sanksi pidana penjara lebih ditingkatkan terhadap orang yang mengunggah konten pornografi. Apalagi di zaman yang serba canggih sekarang, program youtube lebih diminati 
masyarakat di zaman pandemic covid. Jika ditemukan konten youtube yang berbau pornografi maka orang tersebut diberikan hukuman, dan kontennya dihapus.

2. Seharusnya Pemerintah melalui Kemeninfo melakukan pemblokiran situs di Internet. Mulai dari situs dengan konten porno, judi, hingga yang terbaru situs streaming film illegal, sehingga tidak ada lagi akses yang bisa dibuka kalangan anak sekolah apalagi di zaman pandemic covid 19 ini, sekolah dirumah, dimana orangtua tidak bisa memantau anak-anaknya.

3. Seharusnya dalam situasi Pandemic Covid 19 ini anakanak yang masih bersekolah di rumah yang memakai daring orangtua maupun walinya memperhatikan anak-anak tidak menontom konten pornografi jadi diharapkan peran orangtua dalam mengawasi anak-anak menggunaka handpone.

\section{DAFTAR PUSTAKA}

\section{A. Buku}

Atmasasmita Romli 1986, Problema Kenakalan Anak-anak dan Remaja, Armico, Bandung

Arief Barda Nawawi.1998, Beberapa Aspek Kebijakan Penaggulangan dan PenegakanHukum Pidana.: Citra Aditya Bakti, Bandung Agus Rahardjo,, 2002,Cybercrime pemahaman dan upaya pencegahan kejahatan berteknologi, PT.Citra Aditya Bakti, Bandung

Adji Oemar seno, 1997,Mass Media dan Hukum.Cet.II, Erlangga, Jakarta.
Agus Sudibyo, 2004, Ekonomi Politik Media Penyiaran, , LKiS, Yogyakarta

Andi Hamzah, 2012,Fsikologi kejiwaan social, , Pustaka Grafika, Bandung

Chazawi Adam,2005, Tindak Pidana

Mengenai Kesopanan, PT Raja

Grafindo

Persada, Jakarta

Hamzah Andi 1996, Bunga Rampai

Hukum Pidana, , ghalia

Ind onesia, Jakarta

Makarim Edmon, 2003,Kompilasi Hukum Telematika, Raja Grafindo Persada, Jakarta

Muhammad Mufid, 2005,

Komunikasi dan Regulasi Penyiaran, , PrenadaMedia, Jakarta

Siregar, Gomgom, T.P.,Siregar, Suatu Analisis mengenai Tindak Pidana Pencemaran Nama Baik melalui Media Elektronik, PT Refika Aditama, Bandung

Soekanto Soerjono, 2008, Pengantar Penelitian Hukum, Penerbit Universitas Indonesia, Jakarta,

Sunggono

Bambang,1997,Metodologi

Penelitian Hukum,Pt raja Grafindo, Jakarta

Sudarto, 1990, Hukum Pidana I,: Yayasan Sudarto d/a Fakultas Hukum UNDIP, Semarang

B. Perundang undangan

Undang-Undang Nomor 44 Tahun

2008 Tentang Pornografi 
Undang Undang No 8 tahun 1992 tentang Perfiliman. Jo Undang undang No 39 tahun 2009 tentang Perfiliman http://indonesiabaik.id/infografis/por nografi-jangan-unduhsimpan-diperjualbelikan diakses tanggal 07 Agustus 2020

Kitab Undang Undang Hukum

Pidana

\section{Internet/ Jurnal Hukum}

Lalu Abi Yu'lla Maulana, Penjatuhan Sanksi Pidana Terhadap Penyebaran Konten Video Porno mengenai Pencabulan Anak di bawah umu melalui Cyber (Dunia Maya), diakses dalam jurnal Hukum Adigama 2234-5126-2-PB.pdf,

Universitas Tarumanegara, diakses pada 08 mei 2020.

Zainal Abdul Fattah, Perbandingan Konten yang dikecualikan dalam tindak Pidana kesusilaan, diakses dalam situs

https://www.bphn.go.id/data/ documents/perbandingan kon ten yg dikecualikan dlm tin dak pidana kesusilaan.pdf pada tanggal 08 Mei 2020.

Asrini Hanifah, Pengaturan Penegakan Hukum terhadap Pornografi di Internet (Cyberporn) sebagai kejahatan mayantara, dalam situs

https://core.ac.uk/download/p df/12350099.pdf tanggal 08 $\underline{\text { Mei } 2020}$

https://www.indojayanews.com/huku $\underline{\mathrm{m} / \text { perekam-dan-penyebar- }}$ video-terancam-dijerat-pasalberlapis/ diakses tanggal 07 Agustus 2020 